DOI: $10.2478 / \mathrm{v} 10025-007-0007-5$

JOURNAL OF WATER

AND LAND DEVELOPMENT

J. Water Land Dev. No. 10, 2006: 79-89

\title{
Measures for soil water control in Poland
}

\author{
Edward PIERZGALSKI, Jerzy JEZNACH
}

Warsaw Agricultural University, Department of Environmental Improvement; 02-787 Warsaw, Now-ursynowska 159, Poland, tel/fax +48 (22) 59353 55; e-mail: edward_pierzgalski@sggw, jerzy_jeznach@sggw.pl

\begin{abstract}
Polish water resources depend on precipitations, which are variable in time and space. In dry years the water balance is negative in central parts of Poland but sudden thaws and downfalls may result in periodical water excess and dangerous floods almost in the entire country. The retention capacity of artificial reservoirs in Poland permits to store only $6 \%$ of the average annual runoff, which is commonly considered insufficient. Another method to increase retention is soil water control. About fifty percent of soils in Poland consist of light and very light sandy soils with low water capacity. Loams and organogenic soils cover approximately $25 \%$ and $8.5 \%$ area of the country, respectively. Almost half of agricultural lands (48\%) have relatively good water conditions, but the rest requires soil water control measures. An increase of the soil water content could be achieved by changes of soil properties, water table control and soil water management. Modernization and reconstruction of drainage and irrigation systems, which were built mainly in the period 1960-1980, is needed.
\end{abstract}

Key words: drainage, irrigation, soil water retention, subirrigation, water management, water resources

\section{INTRODUCTION}

Main concerns of water management in Poland are both the quantity and quality of water resources. Surface water resources (measured as an average river runoff in many years) are $1660 \mathrm{~m}^{3} \cdot \mathrm{y}^{-1}$ per capita being $28 \%$ of the precipitation sum. This is three times less than the average European surface water resource, which places Poland in the group of ten European countries with the smallest water resources. Fortunately, 90\% of Polish water resources come from Poland's territory, which is advantageous for managing water runoff and protecting water quality. Polish water resources depend on precipitation, which is variable in time and space. The average precipitation sum slightly exceeds $600 \mathrm{~mm}$ a year. In central Poland it is only $500 \mathrm{~mm}$ and in the high mountains situated in the southern part of the country it is $1500 \mathrm{~mm}$. The average precipitation sum varies seasonally and in long term 
periods. The average precipitation sum during wet years can be two times higher than in dry years (Fig. 1) - for example in 1991, the water resource index was only $1100 \mathrm{~m}^{3}$ per capita but in 1975 , it was $2660 \mathrm{~m}^{3}$ per capita (Central Statistical Office - GUS, 2004).

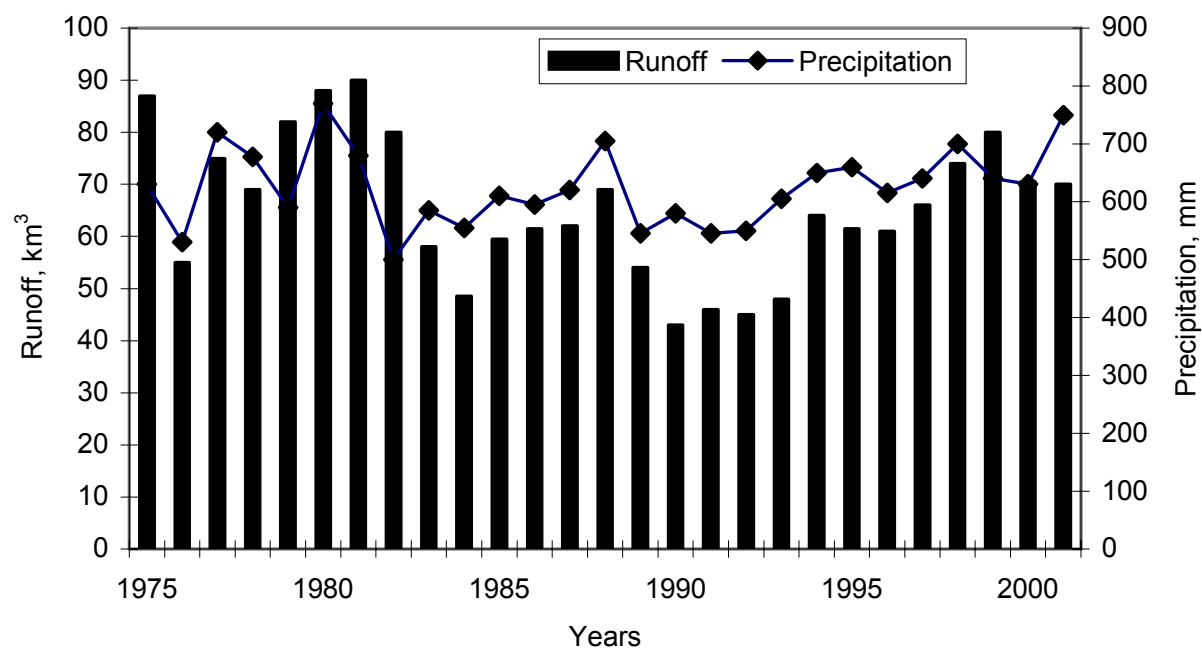

Fig. 1. Annual amount of precipitation and runoff in Poland

Spatial and temporal variability of precipitation cause different weather phenomena. One of them is drought causing crop failure, increased fire risk in forests and drying up of wells. In central part of Poland water balance is negative in dry years (LABĘDZKI, 2004). On the other hand, sudden thaws and downfalls may result in periodical water excess and dangerous floods in almost the entire country.

The periodical shortage and excess of water can be managed by means of storage in natural and artificial reservoirs as well as in the soil and aquifer layers. The retention capacity of artificial reservoirs in Poland permits to store only $6 \%$ of the average annual runoff, which is commonly considered insufficient. In other European countries this factor is much higher. The quantity of water resources and management possibilities depend on the technical infrastructure, which is in a very bad condition. Modernization and reconstruction of flood control and water regulating facilities in agricultural lands and woodlands are needed (BORECKI et al., 2003). 


\section{WATER RETENTION IN POLISH SOILS}

The most common soil types in Poland include brown soils, acid brown soils, grey brown podsolic soils, rusty soils and podsolic soils. A much smaller area is covered by chernozem soils, rendzina soils, black soils and alluvial soils. The soils in Poland are mainly of glacial origin and according to texture they are characterized by a great variability with the predominance of light sandy soils ( $47 \%$ of total area) with low retention capacity. Loams cover approximately $25 \%$ of the country. Relatively high percentage ( $8.5 \%$ ) of area is covered by organogenic soils. The results of measurements of water characteristics in some mineral soils are shown in Table 1, where the values of soil water retention were assumed as a difference of soil water content for matrix potential $\mathrm{pF}=2.0$ and $\mathrm{pF}=4.2$ (ŻAKOWICZ and HEWELKE, 2002).

Table 1. Water retention of mineral soils

\begin{tabular}{|c|c|c|}
\hline \multirow{2}{*}{ Soil type } & Porosity & Soil water retention \\
\hline & \multicolumn{2}{|c|}{$\%$ of volume } \\
\hline Loose sand & 40.0 & 6.0 \\
\hline Loamy sand & 44.0 & 26.5 \\
\hline Sandy loams & 57.5 & 23.4 \\
\hline Silty loam & 53.4 & 24.3 \\
\hline Silty clay & 52.6 & 18.5 \\
\hline
\end{tabular}

The water characteristics of organic soils in relation to the type of peat are given in Table 2 according to Okruszko (BRANDYK and SZATYŁOWICZ, 2002).

Table 2. Water retention of organic soils

\begin{tabular}{l|cc}
\hline \multirow{2}{*}{ Soil type } & Porosity & Soil water retention \\
\cline { 2 - 3 } & \multicolumn{2}{|c}{ \% of volume } \\
\hline Sedge-moss peat R1 & 92.0 & 53.3 \\
Sedge-reed peat R2 & 90.9 & 49.6 \\
Sedge-reed peat R3 & 86.5 & 44.4 \\
Alder peat R2 & 90.1 & 45.5 \\
Alder peat R3 & 88.5 & 35.2 \\
Peaty moorsh & 88.5 & 50.7 \\
Humic moorsh & 83.0 & 38.2 \\
Grainy moorsh & 82.5 & 29.1 \\
\hline
\end{tabular}

$\mathrm{R}$ - different degree of decomposition. 
An analysis of the climatic water balance during six month long (April-September) vegetation period indicates (Fig. 2) the occurrence of negative-valued differences between the rainfalls and evapotranspiration in almost entire central part of Poland (ROJEK, 1987).

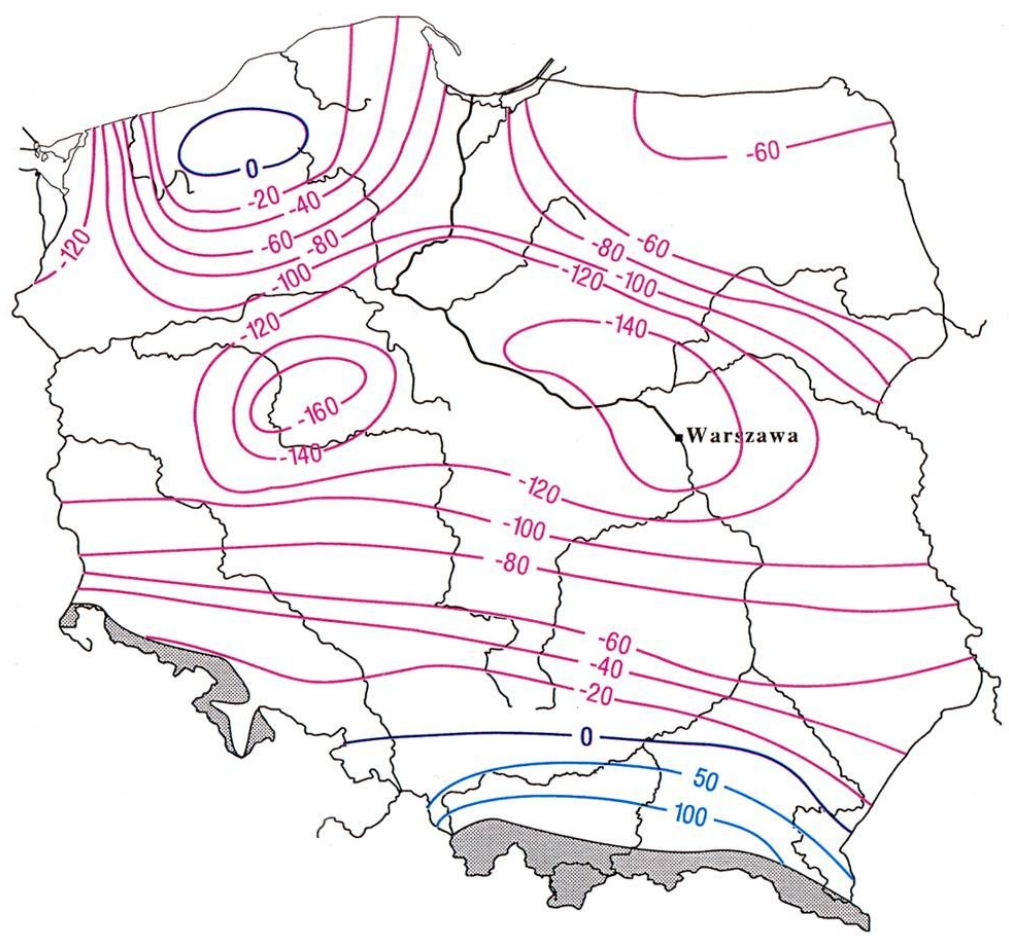

Fig. 2. Climatic water balance in mm from April to September in Poland

Only in the southern territories of Poland, the water balance in this period is positive. It has been found that central part of Poland shows particularly severe deficit of water and is exposed to a risk of becoming a steppe. Hence, agriculture of this area requires protection from the negative effects of water deficiency in the vegetation period. Water deficit occurs especially sharply in light soils with low water holding capacity. Average water conditions of agricultural lands are shown in Table 3.

These conditions have determined the land use structure (Table 4). Most arable lands in Poland are under cereals. Cereals (mainly winter and spring wheat, rye, winter and spring barley) cover about $48 \%$ of arable lands. The share of potatoes and fodder crops is now decreasing. Potatoes are grown on $7 \%$ of arable lands. In the group of fodder crops, the highest yielding crop is maize followed by 
Table 3. Water conditions of agricultural lands

\begin{tabular}{l|c|c}
\hline \multicolumn{1}{c|}{ Water conditions } & $\begin{array}{c}\text { Area } \\
\text { million ha }\end{array}$ & $\begin{array}{c}\text { Area } \\
\%\end{array}$ \\
\hline Very frequent and long term excess of water & 1.0 & 5 \\
Periodical excess of water & 2.9 & 16 \\
Relatively good water conditions & 8.9 & 48 \\
Periodical deficit of water & 4.9 & 27 \\
Permanent deficit of water & 0.7 & 4 \\
\hline
\end{tabular}

Table 4. Land use in Poland (averages for 1999-2001)

\begin{tabular}{|c|c|c|}
\hline Land utilization & $\begin{array}{c}\text { Area } \\
\text { million ha }\end{array}$ & $\begin{array}{c}\text { Area } \\
\%\end{array}$ \\
\hline Agricultural area & 18.41 & 58.9 \\
\hline - arable lands & 14.08 & 76.5 \\
\hline - grasslands & 4.06 & 22.0 \\
\hline - orchards, nurseries & 0.27 & 1.5 \\
\hline Forests & 9.04 & 28.9 \\
\hline Surface waters & 0.82 & 2.6 \\
\hline Urban and industrial areas & 3.00 & 9.6 \\
\hline Total & 31.27 & 100.0 \\
\hline
\end{tabular}

fodder beet. Grasslands are located mainly on alluvial muck soils, muck soils and peat soils. These areas play the most important role in water management due to low location, mostly in flat valleys.

\section{SOIL WATER CONTROL MEASURES}

Soil water content could be increased by:

- agrotechnical measures (changes of soil physical properties),

- drainage and subirrigation (ground water table control),

- irrigation (soil water management).

Soil properties like texture, structure and water retention play an important role in increasing water resources. Total capacity of all water reservoirs in Poland is about 4 billion $\mathrm{m}^{3}$ equal to $22 \mathrm{~mm}$ of soil water on agricultural lands. Soil water holding capacity is affected by soil structure. Good soil structure can be maintained by agrotechnical measures like crop rotation, organic matter additions, and tillage practices. It should be underlined that some practices such as excessive cultivation or tillage of wet soils cause decreased aggregate stability. In sandy soils, aggregate stability is often difficult to maintain due to the low content of organic matter. The 
soils in Poland are commonly acid and that is why lime application is commonly used to decrease soil acidity.

Agricultural production intensity depends to a considerable degree on reclamation measures, which prevent from periodical water excess in soil when floods occur in spring and often also in summer, but they also supplement water deficits during drought periods. Over half of the total agricultural lands and about $15 \%$ of forest areas require drainage and irrigation systems.

Land reclamation in a wide aspect means organizational, economic, agrotechnical and technical measures aiming at permanent improvement of water conditions in catchment area and on agricultural objects, including flood control measures, protection against erosion, phyto-remediation measures, restoration of degraded areas, purification and utilization of waste waters, fish pond installation. These measures should first of all ensure soil fertility to optimise the production of farms. In the stabilization of agricultural production, equally important is also the water supply to rural settlements and the land consolidation.

The extent of drainage and irrigation systems made mainly after 1945 is shown in Figure 3.

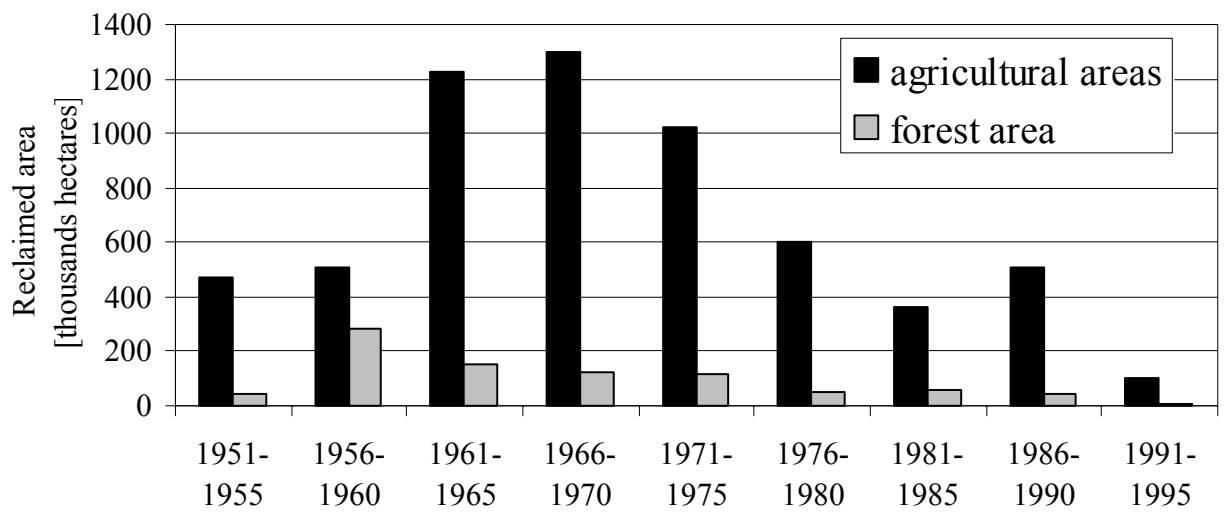

Fig. 3. The extent of land reclamation in agricultural and forest areas

In total, $4.7 \mathrm{mln}$ hectares of arable lands and $1.5 \mathrm{mln}$ hectares of grasslands were reclaimed. More than $90 \%$ of these areas were only drained. Irrigation systems are located mainly in river valleys as subirrigation of grasslands and cover about $0.4 \mathrm{mln}$ hectares, but recently subirrigation has been carried out on about $20 \%$ of these areas. On arable areas, sprinkler irrigation covers no more than 20 thousand hectares. There are also a few objects ( 5 thousand hectares in total) where border irrigation is applied utilizing waste water for agricultural purposes. Microirrigation is used in horticulture in the area of about 4 thousand hectares (LIPIŃSKI, 2003). 
In the regulation of water conditions, different solutions are applied depending on the site in the catchment area and on the kind of plant production.

Permanent grasslands predominate in river valleys. The task of reclamation systems is flood control and keeping ground waters at a level most favourable for the growth of plants. For ground water control, networks of ditches connected with drain pipelines are mainly used (JURCZUK et al., 2004). In spring and after ample rainfalls in the summer periods, such system enables to direct excess water into rivers or water reservoirs (NYC and PODKŁADEK, 2001). The same network permits to apply subirrigation and to supply with water the root layer of plants by means of capillary water rise (KACA et al., 2003). Over 30 percent of grasslands are situated on organic soils which are liable to degradation after drainage. The task of land reclamation systems is to counteract or considerably control this process through a precise moisture regulation in the root layer of plants. It should be noted that apart from positive agricultural results, the technical and agrotechnical activity in valleys caused degradation of soil and worsening of other environmental conditions. The main concept of water regulation in river valleys is to minimize the negative impact of land reclamation on the natural environment through:

- supplementing the existing drainage network with hydraulic structures for ground water table control,

- water recycling in order to reintroduce water and mineral substances into the biological and geological cycle,

- inhibiting the process of organic soil degradation by flooding some excessively drained and degraded areas,

- more widespread use of polder management system for maintaining high water level in the river and in its valley.

In more elevated areas with the predominance of arable lands, two activity lines are possible. Namely: cohesive soils are excessively watered in spring and after ample rainfalls. The drainage systems ensure quick aeration of such soils and allow to start earlier with agrotechnical works. An elongation of the growing season and an improvement of air-water conditions of soil contribute to the increase of yields and to the decrease of their fluctuation amplitude among particular years. On light soils with low water holding capacity and rather deep ground water table, periodical water deficiencies occur in the growing season. On such soils surface irrigation systems (sprinkler and microirrigation) are mainly applied.

In the period 1959-1995, about $0.9 \mathrm{mln}$ hectares of forest areas were reclaimed, out of which about $0.8 \mathrm{mln}$ hectares had already been reclaimed before. It means that the range of newly drained areas was relatively small. Re-evaluation of forest functions in the ecosystems stressed the importance of water as a factor preconditioning the balanced development of forests. It became clear that limitation of water is one of the basic factors affecting forest sustainability. Water conditions in forests are determined by climatic, physico-geographical and anthropogenic fac- 
tors, including forest management (PIERZGALSKI et al., 2002). Prevention from negative phenomena caused by these factors through rational water management is necessary for balanced and multifunctional forest management.

The application of hydro-melioration technical treatments is justified in the following cases:

- in areas affected by groundwater level disturbances and by changing habitat conditions,

- melioration facilities with permanently disturbed, yet stable water conditions, adjusted to the needs of stands growing there,

- changes of land use in forestry - e.g. establishing of forest nurseries and tree plantations, afforestation of water-logged areas, etc.

Controlled outflow systems should be the main technique of regulating water relations in forest habitats. They drain water in periods of its excess, and hamper its outflow in periods of water deficiency in agreement with the current needs of forest ecosystem. Drainage systems composed of irregular and regular network of ditches should be used only in special cases, e.g. after the occurrence of natural disasters (fire, flood), or in habitats with negative changes in water relations when it is necessary to restore or preserve the water conditions adequate for a given type of forest habitat.

Irrigation in forest habitats is mainly used in forest nurseries. Apart from controlled drainage, subirrigation and other irrigation systems are sporadically used in forests. Irrigation systems are used in forest nurseries to assure reliability of the production of good quality seedlings. Permeable soils with wash type water supply are prevailing in forest nurseries. The deep level of groundwater has no effect on water content of the top soil layer because capillary rising does not reach the root system. Frequent weather anomalies and low usable water capacity in most soil types make irrigation of forest nurseries a common practice nowadays.

In forest nurseries, according to present state of the art, automated irrigation and microirrigation systems should be applied to assure high water use efficiency and the possibility to control soil moisture suitably to the current needs of tree seedlings.

Rational water management in forests is also important for water relations in the entire country. Water-retaining properties of forests play a great role in shaping water resources and in controlling such phenomena as droughts and floods. Interception, retentive properties of forest litter and relatively high forest soil permeability enable to retain part of precipitation and to replace surface runoffs by groundwater runoff. As a result, forests increase the underground water resources and, at the same time, they reduce the flood wave peak in rivers reducing thereby flood hazards. The importance of forest effect for water circulation in lowlands is slightly different than that in mountain forests which, in addition to reducing flood waves, very well protect soil against erosion. Supplying of water courses with underflow 
waters during climatic droughts is also considered to be an important role of forests. Discharges in watercourses flowing out of forests are then much larger then those in water courses passing through agricultural catchment areas. The role of forests in shaping water quality increases with the increase of environmental contamination.

To stop depletion of water resources and to restrain the more and more frequent overdrying of habitats, the surface water retention in forest areas should be increased (MIODUSZEWSKI, 2004). The programme of the increase of retention is being implemented in Poland based on agreements made in 1995 and again in 2003 between the Minister of Environmental Protection, Natural Resources and Forestry on the one hand and the Minister of Agriculture and Rural Development on the other.

\section{CONCLUSIONS}

1. About fifty percent of soils in Poland are light and very light sandy soils with low water capacity. Loams and organogenic soils cover approximately $25 \%$ and $8.5 \%$ area of the country, respectively. Most of the area (48\%) of agricultural land has relatively good water conditions, but the rest requires soil water control measures.

2. Hydrological conditions in Poland are greatly unfavourable due to the amount of precipitation and to its variations in time and space. Technical measures for water management and for the enlargement of water resources have too small capacity and should be improved. Also the drainage and irrigation systems built mainly in the period 1960-1980, require now a modernization and reconstruction.

3 . Trends of decreasing water resources in forests are observed in some regions and periods. They should be prevented by controlling the outflow, increasing the number of small surface reservoirs and by improving soil properties with the use of proper silvicultural treatments.

\section{REFERENCES}

1. Borecki T., Pierzgalski E. Żelazo J., 2003. Aktualny stan i niektóre zadania gospodarki wodnej w Polsce ze szczególnym uwzględnieniem obszarów wiejskich. (Present status and some tasks of water management in Poland with special regard to rural areas). Wiad. Melior. 3: 103-108.

2. BRandyk T., SzatyŁowicz J., 2002. Fizyczne właściwości torfu. W: Torfowiska i torf. (Physical properties of peat. In: Peatlands and Peat). Ed. P. Ilnicki. Poznań, Wydaw. AR: 480-426.

3. LIPIŃSKI J., 2003. Stan i potrzeby melioracji wodnych. (State and needs of water reclamation). Wiad. Melior. 3: 115-117.

4. JurczuK S., LipińSKi J., Bem-BAJena B., ŁeMPicka A., PAwlik-Dobrowolski J., 2004: Nawodnienia podsiąkowe jako podstawa zwiększenia retencji wodnej małych dolin rzecznych. 
(Subirrigation as a base for increasing water retention of small river valleys). Falenty, Wydaw. IMUZ: 63.

5. KaCa E., ŁabęDzki L., Chrzanowski S., CZaplak I., Kasperska-Wolowicz W., 2003. Gospodarowanie zapasami wody użytecznej gleb torfowo-murszowych w warunkach regulowanego odpływu w różnych regionach agroklimatycznych Polski. (Management of available water resources in peat-moorsh soils by controlled drainage in various agroclimatic regions in Poland). Woda Środ. Obsz. Wiej. Rozpr. monogr. 9: 118.

6. ŁABĘDZKi L., 2004. Problematyka susz w Polsce. (Drought problems in Poland). Woda Środ. Obsz. Wiej. t. 4 z. 1(10): 47-66.

7. MioduszewSKI W., 2004. Small retention as a protection of water resources in rural areas. Ann. Warsaw Agricult. Univ. Land Reclamation 35: 47-54.

8. NYC K., POKŁADEK R., 2001. Ekologiczne skutki stosowania regulowanego odpływu w dolinach rzecznych. (Ecological effects of controlled outflow application in the river valleys). Wiad. Melior. 4: $163-165$.

9. Pierzgalski E, Boczoń A., TyszKa J., 2002. Zmienność opadów i położenia wód gruntowych w Białowieskim Parku Narodowym. (Variability of precipitation and ground water level in the Białowieża National Park). Kosmos t. $51 \mathrm{nr}$ 4: 415-425.

10. ROJeK M., 1987. The time and spatial distribution of climatic and agricultural-climatic water balances on the territory of Poland. Zesz. Nauk. AR Wroc. Treatises 62: 67.

11. Żakowicz S., Hewelke P., 2002. Podstawy inżynierii środowiska. (Principle of environmental engineering). Warszawa, Wydaw. SGGW: 114-116.

\section{STRESZCZENIE}

\section{Sposoby regulowania stosunków wodnych w glebach w Polsce}

Słowa kluczowe: gospodarowanie woda, nawodnienia, odwodnienia, woda w glebie, zasoby wodne

W pracy scharakteryzowano główne problemy związane z zasobami wodnymi w Polsce oraz koniecznością regulacji stosunków wodnych na obszarach rolniczych i leśnych. Problemy ilościowe gospodarki wodnej w Polsce związane z występowaniem trwałych lub okresowych deficytów względnie nadmiarów wody są skutkiem zmienności czasowo-przestrzennej opadów atmosferycznych oraz stanu infrastruktury wodnej. Opady charakteryzują się dużą zmiennością zarówno w okresach wieloletnich, jak i w ciagu roku. Sumy średnich opadów rocznych w latach mokrych mogą być ponad 2-krotnie większe od opadów w latach suchych. Częstym zjawiskiem jest występowanie susz, powodujących klęski nieurodzaju, wzrost zagrożenia pożarowego lasów, wysychanie studni itp. Zróżnicowanie przestrzenne opadów natomiast sprawia, że w centralnej części Polski bilans wodny, zwłaszcza w latach suchszych, jest ujemny. $Z$ drugiej zaś strony gwałtowne roztopy i zjawiska ekstremalne w postaci opadów nawalnych powodują okresowe nadmiary wód i powodzie. $Z$ tych niekorzystnych zjawisk wynikają podstawowe zadania gospodarki wodnej na terenach niezurbanizowanych, do których należą: zapewnienie zaopatrzenia w wodę ludności i poszczególnych gałęzi gospodarki naro- 
dowej, ochrona przed powodzią, regulacja stosunków wodnych na obszarach użytkowanych rolniczo, zapewnienie trwałości ekosystemów przyrodniczych, w tym lasów. Wyrównanie okresowych braków lub nadmiarów wody osiąga się w różny sposób, generalnie poprzez zmagazynowanie wody w zbiornikach powierzchniowych naturalnych i sztucznych, a także w glebie i w podziemnych warstwach wodonośnych. Pojemność retencyjna sztucznych zbiorników wodnych w Polsce umożliwia zmagazynowanie jedynie $6 \%$ średniego rocznego odpływu i jest powszechnie uznawana za niewystarczającą.

Obieg wody w zlewniach, zdolności produkcyjne gleb, a także szkody erozyjne zależą w dużej mierze od urządzeń melioracji szczegółowych. Obecnie ponad $20 \%$ wykonanych urządzeń $\mathrm{w}$ okresie powojennym uległo dekapitalizacji i przy obecnym poziomie inwestycji w najbliższych 10 latach osiagnie wielkość około $30 \%$. Oznacza to znaczne ograniczenie wykorzystania potencjalnych zdolności produkcyjnych gleb oraz powiększanie strat w okresach ekstremalnych, zarówno susz, jak i powodzi. Jest to jedno $\mathrm{z}$ większych zagrożeń racjonalnej gospodarki wodnej na obszarach rolnych i leśnych. W dużym stopniu, zarówno na terenach rolniczych, jak i leśnych, są one zużyte i wymagają odbudowy, a najczęściej modernizacji. W pracy podkreślono konieczność uwzględniania wymogów ochrony zasobów wodnych i pozostałych elementów środowiska i to zarówno w fazie projektowania urządzeń melioracyjnych, jak i ich eksploatacji.

Reviewers:

Prof. Waldemar Mioduszewski

Prof. Czestaw Przybyta 